\title{
A face oculta(da) dos movimentos sociais: trânsito institucional e intersecção Estado- Movimento - uma análise do movimento de Economia Solidária no Rio Grande do Sul
}

\section{Resumo}

As relações entre movimentos sociais, partidos políticos e Estado tornaramse, nas últimas décadas, um dos focos centrais de problematização teórica e investigação empírica no campo de estudos sobre movimentos sociais. Inserindo-se nesse debate, o presente artigo propõe uma perspectiva de análise que possibilite apreender diferentes padrões de relação entre política institucionalizada e política não institucionalizada e, particularmente, como tais padrões oportunizam processos distintos de organização e atuação dos movimentos sociais. Para explorar as possibilidades analíticas de tal perspectiva, aborda-se a trajetória de militantes do denominado movimento de economia solidária no estado do Rio Grande do Sul. Através dessas trajetórias, é possível identificar um processo organizativo que não apenas não se dá externamente ao Estado, mas é, em grande medida, fomentado por agentes e políticas governamentais. Ao contrário de abordar e criticar tal processo como exemplo de cooptação, instrumentalização ou colonização do movimento de economia solidária pelo Estado, busca-se mostrar que ele é fruto de um complexo padrão de relações entre sociedade civil e Estado, mediadas por partidos políticos (e, particularmente, pelo Partido dos Trabalhadores - PT), que emerge e se consolida no Brasil ao longo dos últimos 25 anos.

Palavras-chave: Movimentos sociais. Relações Estado/sociedade civil/partidos políticos. Política não institucionalizada. Movimento de economia solidária.

\footnotetext{
* Doutor em Sociologia pela Universidade Federal do Rio Grande do Sul (UFRGS), pós-doutorado pelo Watson Institute for International Studies/Brown University (EUA). Professor do Programa de Pós-Graduação em Sociologia (PPGS) e do Programa de Pós-Graduação em Desenvolvimento Rural (PGDR) da UFRGS. Atualmente é Coordenador do PPGS desta mesma instituição. E-mail: mksilva@ufrgs.br

** Doutorando pelo Programa de Pós-Graduação em Sociologia da UFRGS. E-mail: gerson. oliveira@ufrgs.br
} 
Sociologias, Porto Alegre, ano 13, no 28, set./dez. 2011, p. 86-124

[N]ão há nenhuma razão para esperar que protesto e ação política convencional devam ser substitutas, com grupos abandonando o primeiro na medida em que eles se tornam capazes de usar a última. Enquanto alguns grupos podem, em diferentes momentos, ser mais "in", no sentido de serem mais alinhados e integrados com as autoridades institucionais, enquanto outros grupos são mais "out", não há nem uma simples divisão qualitativa nem um cruzamento "de uma vez por todas" de alguma linha separando claramente contestadores e membros. É mais correto pensar em um continuum de alinhamento e influência, com alguns grupos tendo muito pouco acesso e influência através da política convencional, outros tendo um pouco mais e outros ainda tendo muito; mas grupos podem mover-se para cima e para baixo neste continuum muito rapidamente, dependendo das mudanças no Estado e nos alinhamentos partidários. Protestar pode, algumas vezes, ser um meio de mover-se para cima neste continuum, ou uma resposta a um movimento de descida, ou mesmo uma opção que se torna mais fácil e mais disponível quando o acesso institucional aumenta (...). As dinâmicas do protesto, então, têm uma relação contingente e complexa com a integração dos grupos na política institucionalizada. A noção de que existem grupos "in" e grupos "out", e que os últimos se engajam em protesto enquanto os primeiros se engajam em política, é uma caricatura com pouca relação com a realidade. (Goldstone, 2003b, p. 9)

\section{Introdução}

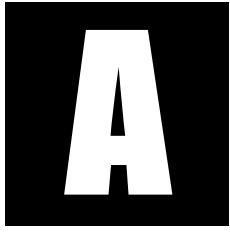

nalisando algumas importantes obras da literatura recente sobre movimentos sociais (Giugni, McAdam e Tilly, 1998; Goldstone, 2003a; McAdam, Tarrow e Tilly, 2001; Tarrow, 2009; Tilly, 2006; Tilly e Tarrow, 2007), assim como alguns dos artigos que integram este dossiê (Auyero; McAdam e Tarrow; Von Büllow e Abers), observa-se que as relações entre movimentos sociais, partidos políticos e Estado - ou, mais amplamente, entre política institucionalizada e política não institucionalizada (Goldstone, 2003b) - tornaram-se um dos focos centrais de 
problematização teórica e investigação empírica nesse campo de estudos (Alonso, 2009; Silva, 2010).

Inserindo-se nesse debate, o presente artigo busca dar um passo além da defesa de uma abordagem relacional no estudo dos movimentos sociais, propondo uma perspectiva de análise que possibilite apreender diferentes padrões de relação entre política institucionalizada e política não institucionalizada e, particularmente, como tais padrões oportunizam processos distintos de organização e atuação dos movimentos sociais.

Para explorar as possibilidades analíticas de tal perspectiva, aborda-se a trajetória de militantes do denominado movimento de economia solidária no estado do Rio Grande do Sul. ${ }^{1}$ Através dessas trajetórias, é possível identificar um processo organizativo que não apenas não se dá externamente ao Estado, mas é, em grande medida, fomentado por agentes e políticas governamentais. Ao contrário de abordar e criticar tal processo como exemplo de cooptação, instrumentalização ou colonização do movimento de economia solidária pelo Estado, busca-se mostrar que ele é fruto de um complexo padrão de relações entre sociedade civil e Estado, mediadas por partidos políticos (e, particularmente, pelo Partido dos Trabalhadores - PT), que emerge e se consolida no Brasil ao longo dos últimos 25 anos.

\section{Entre outsiders e membros: padrões de relação sociedade civil-Estado e variações nas dinâmicas da contestação}

O campo de estudos sobre movimentos sociais e, mais amplamente, sociedade civil no Brasil encontra-se ainda muito marcado pelo seu contexto de origem. Conformado entre o final dos anos 1970 e os anos

1 Uma apresentação mais aprofundada dos resultados empíricos da pesquisa que fundamenta este artigo pode ser encontrada em Oliveira (2011). 
1980, esse campo de estudos teve como objetos de análise processos organizativos e contestatórios de segmentos da sociedade brasileira, os quais, naquele momento, encontravam-se excluídos das oportunidades de participação político-institucional (ou que avaliavam as oportunidades existentes como limitadas e, no limite, ineficazes) por um regime autoritário ${ }^{2}$. Nesse sentido, as análises daquele momento (Evers, 1983; Sader, 1988) tendiam a apreender os movimentos de contestação emergentes como processos marcados por uma externalidade em relação à políticainstitucional, na medida em que envolviam e/ou constituíam organizações que se caracterizavam efetivamente como outsiders em relação à política instituída e que tinham na ação contestatória uma das poucas possibilidades de expressão política.

Tal interpretação, mesmo que hoje possa ser apontado seu equívoco em tratar externalidade como ausência de relação (e não como uma forma de relação específica), mostrou-se bastante adequada para o estudo de organizações e movimentos sociais contestadores no contexto autoritário. Como salienta Telles (1988, p.280), a ideia da "sociedade contra o Estado" não deve ser criticada apenas como simplismo ou ilusão de ótica,

pois há nela os sinais de uma experiência histórica na qual a violência e a exclusão política apareciam como fatores determinantes, de tal modo que, frente ao Estado, visto como

\footnotetext{
$2 \mathrm{Na}$ verdade, para uma parcela importante da literatura, mais do que uma especificidade do autoritarismo do regime ditatorial brasileiro, a exclusão política tendia a ser vista como uma característica inerente do que se conceituava no período como o "capitalismo monopolista de Estado" (Castells, 1976; Moisés, 1982; Oliveira, 1978). Segundo Castells, um dos autores de referência da literatura brasileira sobre movimentos sociais urbanos nos anos 1980, se é verdade que o Estado exprime, em última instância e através de todas as mediações necessárias, os interesses do conjunto das classes dominantes, a planificação urbana não pode ser instrumento de mudança social, mas de dominação, de integração e de regulação das contradições (1976, p.16). Neste sentido, conclui o autor, A verdadeira origem da mudança e da inovação da cidade está nos Movimentos Sociais Urbanos e não nas instituições (1976, p.17). Para uma (auto) crítica do "deducionismo das condições objetivas" presente na literatura sobre movimentos sociais urbanos, ver Kowarick (2000).
} 
polo opressor comum, a sociedade aparecia como alternativa política, como lugar no qual o desejo de liberdade poderia alimentar-se e traduzir-se numa ação possível.

O problema, no entanto, foi a universalização dessa interpretação, tomando a externalidade e o repertório ${ }^{3}$ confrontacional como características constitutivas e inerentes à "natureza" dos movimentos sociais e não como aspectos conjunturais relacionados a um determinado contexto político específico (autoritário e excludente). Nesse sentido, outras formas de relação passaram a ser tratadas como desvios frente a um modelo teórico-normativo que estabelecia não apenas o "ser", mas também o "dever ser" (combativos, transformadores, autônomos, não institucionais, etc.) dos movimentos sociais.

O processo de redemocratização do país e, mais especificamente, a consolidação de novos atores da política institucional originados no (e produtores do) ciclo de protesto ${ }^{4}$ que tem seu ápice nos anos 80 (entre os quais, o mais destacado é o PT), no entanto, geraram uma profunda mudança nas oportunidades de acesso à política institucional por parte das organizações de movimentos sociais. Seja através da participação em novos espaços institucionais abertos às representações da sociedade, seja pelo envolvimento na implementação de políticas públicas, seja pelo

3 O conceito de repertório de ação coletiva foi elaborado por Charles Tilly, que o define da seguinte forma: A palavra repertório identifica um conjunto limitado de rotinas que são aprendidas, compartilhadas e encenadas através de um processo relativamente deliberado de escolha. Repertórios são criações culturais aprendidas, mas eles não descendem de filosofias abstratas ou tomam forma como resultado de propaganda política; eles emergem da luta (1995, p.26). 4 O conceito de ciclo de protesto foi desenvolvido por Tarrow $(1989,2009)$, para quem ciclos de protesto (...) são melhor caracterizados como agregados de episódios de ação coletiva, parcialmente autônomos e parcialmente interdependentes, nos quais emergem e evoluem novas formas de ação, um setor de movimentos sociais cresce e muda sua composição e novas oportunidades políticas se desenvolvem, em parte como resultado das ações, temas e conquistas de movimentos prévios no ciclo (1989, p.50-51). Para um uso deste conceito na análise da redemocratização brasileira, ver Hochstetler (1997). 
acesso a recursos governamentais diversos, seja ainda pela ocupação de posições diretamente no interior do aparelho do Estado, o fato é que uma parcela significativa das organizações de movimentos sociais passou, nas últimas três décadas, por um marcante processo de inserção como membros efetivos (mesmo que, muitas vezes, subalternos) de redes de políticas públicas $^{5}$ em praticamente todos os setores do Estado brasileiro. Como salientam Friedman e Hochstetler (2002, p.37),

O regime de representação no Brasil, desde 1985, tem sido orientado para alternativas mais institucionalizadas. Tanto o Estado quanto as organizações da sociedade civil têm trabaIhado para criar espaços deliberativos e oportunidades permanentes para a participação das organizações da sociedade civil. Poucos sistemas políticos têm uma participação das organizações da sociedade civil tão ampla e regulamentada.

Tal processo, no entanto, não foi devidamente acompanhado pelas formulações teóricas dos pesquisadores brasileiros dos movimentos sociais, muitos dos quais se encontram pouco instrumentalizados para compreender e explicar padrões de relação, formas de organização e repertórios de ação que se afastam de maneira relativamente radical daquele "modelo de movimento social" do período da redemocratização.

5 De acordo com Kriesi, Adam e Jochum (2006, p.341), a construção de políticas públicas ocorre em sub-sistemas de política específicos, que operam de forma mais ou menos independente e paralela uns em relação aos outros. Tais subsistemas de política consistem de um grande número de atores que lidam com temas de política específicos. Processos políticos nestes subsistemas não são controlados somente pelos atores estatais; antes, eles são caracterizados pelas interações de atores públicos e privados. A preocupação com uma ampla variedade de atores e suas interações tem dado proeminência ao conceito de redes de políticas. O termo "rede de políticas" (...) deve ser entendido com uma denominação genérica que abarca diferentes formas de relações entre atores estatais e privados. Apesar de haver um significativo distanciamento entre os pesquisadores dos movimentos sociais e aqueles dedicados ao tema das políticas públicas, uma fértil aproximação entre esses campos de pesquisa pode ser encontrada em Meyer, Jenness e Ingram (2005). 
Partindo dos pressupostos relacionais enfatizados por diversos autores contemporâneos (Goldstone, 2004; Tarrow e Tilly, 2007; Tilly, 2006), adota-se neste artigo o argumento desenvolvido por Banaszak (2005) de que, ao invés de assumir a perspectiva de que existiria um padrão único de relações entre movimentos sociais e Estado, o mais correto seria pensar tais relações como conformando um continuum que pode ser sintetizado na Figura a seguir ${ }^{6}$ :

Figura 1: Tipos de inclusão de movimento como continuum

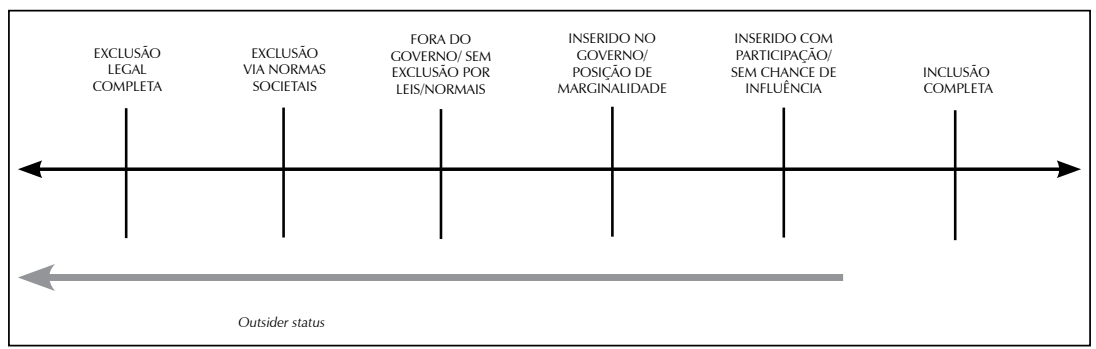

Fonte: BANASZAK, 2005, p. 156

De acordo com esse argumento, as situações de externalidade dos movimentos sociais frente ao Estado, em função da exclusão daqueles dos processos e mecanismos disponíveis para o acesso aos atores e instituições político-administrativas, seriam uma das possibilidades empíricas de configuração dessa relação. No extremo oposto, contudo, se colocariam

6 Esta perspectiva confronta a definição de movimentos sociais elaborada por autores do chamado Modelo do Processo Político, na década de 1980, os quais interpretavam os movimentos sociais como o recurso de ação política de categorias e grupos outsiders em relação à política institucional. Tal interpretação se expressa claramente na definição de McAdam (1997, p.173), para quem os movimentos deveriam ser analisados como tentativas racionais feitas por grupos excluídos no sentido de mobilizar suficiente poder político para promover interesses coletivos através de meios não-institucionalizados (sublinhado nosso). Uma crítica a esta visão pode ser encontrada em Goldstone (2003b). 
casos nos quais os movimentos sociais teriam acesso àqueles atores e instituições enquanto membros efetivos da polity. Entre esses dois polos, por sua vez, estariam os casos caracterizados por níveis e formas variáveis de inclusão/exclusão dos movimentos sociais.

Segundo Banaszak (2005), uma das possibilidades de relação entre movimentos sociais e Estado que desafia a visão externalista dominante nas literaturas de movimentos sociais e políticas públicas é o que a autora denomina de intersecção Estado-Movimento. Nas suas palavras, os movimentos podem compartilhar membros com o Estado. O compartiIhamento ocorre porque Estados, como conjuntos de instituições, podem ter membros que são também ativistas de movimentos através da participação em organizações de movimentos sociais, como "contribuintes ocasionais" ou ainda participando em "atividades espontâneas e não organizadas" (...). Eu denomino este compartilhamento de intersecção Estado-Movimento. Além disto, eu defendo que o alcance, localização e contexto histórico desta intersecção Estado-Movimento influencia o desenvolvimento, as estratégias e os resultados do movimento. (p. 150-151)

Adaptando o esquema de Banaszak para interpretar as mudanças nos padrões de inclusão/exclusão político-institucional dos movimentos sociais no Brasil7, dos anos 1970 até os dias atuais, poderíamos identificar um processo que, mesmo não sendo linear, se caracteriza por um nível crescente de inclusão institucional das organizações da sociedade civil (incluindo as organizações de movimentos sociais). Tal processo tem seu ápice nas gestões do presidente Luiz Inácio Lula da Silva (2003-2010)ํ, quando se observa a presença de uma expressiva intersecção Estado-Movimentos.

7 É preciso destacar que esta figura apreende, ainda que de forma simplista, a dinâmica de inclusão/exclusão em nível federal. As temporalidades e dinâmicas nos níveis estaduais e municipais, por sua vez, podem apresentar profundas diferenças em relação àquela.

8 É preciso destacar que a luta por incorporação institucional foi uma característica constitutiva do processo de redemocratização brasileiro desde seu início (mesmo que, neste início, o dis- 
A compreensão desse processo de incorporação e, particularmente, da dimensão e forma assumida por tal processo a partir de 2003 coloca a necessidade de incluir na análise um elemento pouco abordado pelos pesquisadores dos movimentos sociais: a relação entre partidos políticos, organizações e movimentos sociais.

Como destacam McAdam e Tarrow no artigo que integra este dossiê, na medida em que a interpretação dos movimentos sociais produzida tanto por cientistas políticos quanto por sociólogos tendeu a tratá-los como atores externos e, no limite, opostos à política institucional, a relação dos movimentos com partidos políticos acabou sendo secundarizada e, por vezes, simplesmente ignorada.

Na literatura brasileira, por sua vez, essa relação tende a aparecer de forma ambígua. Por um lado, os partidos políticos são analisados de modo crítico, enquanto "incômodos hóspedes" (Barreira, 1986) que tenderiam a instrumentalizar as organizações de movimentos sociais, desvirtuando a autonomia e combatividade das mesmas. Por outro lado, os partidos são vistos como o elemento necessário para que as reivindicações e propostas daquelas organizações tenham efetividade política (Boschi, 1987). Nos dois casos, porém, prevalece a abordagem dos partidos políticos como atores claramente distintos das organizações de movimentos sociais e vice-versa.

Assim como as relações entre movimentos sociais e Estado apresentam uma grande variação em termos de graus e mecanismos de inclusão/

curso de muitas organizações de movimentos sociais estivesse marcado por um claro viés antiinstitucional). Nesse sentido, por exemplo, já na década de 1980 se observam experiências pioneiras de inovação institucional voltadas à criação de novos canais de participação social, que irão se disseminar geográfica e setorialmente na década de 1990 e 2000. Da mesma forma, as propostas de reforma do Estado elaboradas e parcialmente implementadas nos dois mandatos de Fernando Henrique Cardoso (1995-2003) tinham como elementos centrais a participação social e o envolvimento da sociedade civil na implementação de políticas públicas (Bresser Pereira, 1999). Para uma discussão sobre a incorporação institucional (sem excluir a contestação) como uma característica dos movimentos sociais em sociedade complexas, ver Giugni e Passy (1998). 
exclusão político-institucional dos primeiros, sustenta-se neste artigo que as relações entre movimentos sociais e partidos também devem ser pensadas não através de um padrão único de relações, mas sim como um continuum de possibilidades. Adaptando a tipologia desenvolvida por Hanagan (1998), podem-se definir três padrões principais de relação:

Independência - ocorre quando há uma separação significativa entre política institucional e política não institucional, causada, em geral, pela exclusão política característica de contextos autoritários, fazendo com que grupos contestadores tenham que desenvolver mecanismos extrainstitucionais de expressão política e, no limite, estabelecer uma relação de competição com os partidos instituídos através da criação de novas organizações políticas (e, mesmo, partidárias).

Cooperação - ocorre quando partido e movimento, mantendo suas fronteiras, estabelecem formas cooperativas de relação, seja em termos de apoio de organizações do movimento a certo partido em momentos de disputa eleitoral, seja em termos da defesa pelo partido de reivindicações e propostas de determinadas organizações de movimento ${ }^{9}$; Interpenetração - ocorre quando as fronteiras entre partido e movimento apresentam uma relativa diluição (cujo grau pode ser bastante variável), com o compartilhamento de militantes, marcos interpretativos, orientações ideológicas e estruturas organizativas.

Enquanto a primeira situação tende a ser abordada pela literatura que enfatiza (e, em muitos casos, defende) a externalidade dos movimentos em relação à política institucional e a segunda situação tem recebido crescente atenção dos pesquisadores (McAdam e Tarrow neste

9 As formas e intensidades da cooperação podem ser bastante variáveis, indo desde coalizões pontuais em torno de propostas específicas até articulações permanentes em função de convergências ideológicas e/ou estratégicas. 
dossiê), observa-se uma significativa lacuna no tratamento das relações de interpenetração nas pesquisas sobre movimentos sociais. Tal lacuna é particularmente grave no caso brasileiro, na medida em que, segundo argumento proposto neste artigo, as relações de interpenetração tendem a apresentar grande centralidade na conformação do tecido associativo brasileiro e, particularmente, dos movimentos sociais. ${ }^{10}$

A interpenetração se expressa claramente naquilo que Mische (1997; 2008) denominou "militância múltipla", que caracterizaria a atuação de parcela significativa dos ativistas políticos no Brasil (especialmente, mas não exclusivamente, aqueles situados à esquerda do espectro político). Segundo a autora, na medida em que se inserem e desenvolvem seu ativismo em diversas organizações sociais e, também, partidos políticos, esses militantes criam conexões e sobreposições entre essas esferas de ação, levando, em certos casos, a uma relativa diluição de suas fronteiras.

Da mesma forma, a importância da interpenetração também pode ser identificada nas análises de Coradini $(2001,2007)$ sobre a conformação do capital político de candidatos às eleições no estado do Rio Grande do Sul. A partir dessas análises, observa-se que, para alguns partidos políticos (com destaque para o PT), a trajetória de engajamento em organizações e movimentos sociais (conformando um "capital associativo") constitui um recurso importante do ponto de vista da legitimação e, em vários casos, da viabilização eleitoral das candidaturas.

10 Enfatizando o caráter excepcional desta relação partido-movimento no caso brasileiro, Hochstetler (2008, p.34-35) salienta que Relacionamentos estreitos entre partidos e movimentos sociais são escassos, sendo o fenômeno do Partido Verde uma notável exceção. Um partido político como o PT, com fortes bases em sindicatos e um conjunto de movimentos sociais, é então altamente incomum, mas proporciona um caso provocativo para pensar sobre as possibilidades e limites de vínculos estreitos entre partidos e organizações da sociedade civil. Para um argumento que ressalta, ao contrário, que relações estreitas entre partidos-movimentos tendem a ser muito mais disseminadas, ver Goldstone (2003b). Sobre as relações estreitas entre o sindicalismo cutista e o PT, ver Riethof (2004). 
Por fim, a centralidade da interpenetração também é corroborada por pesquisas recentes sobre trajetórias de militantes de organizações sociais no Brasil (Feltran, 2006; Moreno e Almeida, 2009; Seidl, 2009), as quais identificam o engajamento partidário como uma característica predominante entre tais militantes.

É exatamente essa importância da interpenetração partido-movimento que, somada a outros elementos que não serão abordados neste artigo ${ }^{11}$, propicia não apenas compreender a dimensão assumida pela incorporação institucional entre organizações e movimentos sociais no Brasil nas últimas duas décadas, mas também permite construir argumentos que possibilitem explicar a forma como vem se dando essa incorporação - com um alto grau de intersecção Estado-Movimentos.

De um lado, a eleição de um candidato do partido político no qual militam indivíduos que também integram organizações e movimentos sociais (sendo que, por vezes, o próprio eleito também é um militante daquelas organizações e movimentos) para um cargo no Legislativo ou, especialmente, no Executivo, altera significativamente as oportunidades de acesso institucional não somente desses indivíduos, mas também, através deles, das organizações e dos movimentos nos quais eles atuam. Nesse sentido, as progressivas vitórias eleitorais de um partido como o PT, com um forte enraizamento no universo associativo brasileiro, proporcionaram que parcelas crescentes deste universo passassem a ter acesso a um Estado caracterizado por uma maior permeabilidade a suas demandas e propostas ${ }^{12}$. Tal processo tem seu ponto culminante, obviamente, com a

11 Uma característica institucional de extrema relevância para os processos analisados neste artigo é o significativo número de Cargos de Confiança e/ou Cargos de Comissão na estrutura do Estado brasileiro. A importância dos indivíduos ocupantes desses cargos na formulação e implementação de políticas públicas que respondem aos interesses de organizações e movimentos de pequenos agricultores no Brasil pode ser vista em Muller, Silva e Schneider (2007). $12 \mathrm{O}$ uso do conceito de permeabilidade para abordar as relações entre agentes públicos e privados no Brasil pode ser visto em Marques (1999, 2000) e Muller, Silva e Schneider (2007). 
eleição de Lula à Presidência da República, em 2003, e os governos liderados pelo $\mathrm{PT}$ que se sucedem desde então ${ }^{13}$.

De outro lado, devido à interpenetração partido-movimento, essa incorporação institucional tende a se caracterizar não apenas pela abertura ou pela maior permeabilidade das instituições às demandas e propostas de organizações de movimentos sociais, mas também pela recorrência de um mecanismo central na conformação daquela permeabilidade no Brasil: o trânsito institucional.

O trânsito institucional se caracteriza pelo deslocamento contínuo de militantes sociais-partidários por diferentes espaços de atuação (organizações sociais, partidos, fóruns institucionais e posições governamentais), o qual é, em grande medida, possibilitado pela interpenetração partido-movimento. Assim, vitórias e derrotas eleitorais tendem a produzir um trânsito significativo de militantes da sociedade civil para o governo e vice-versa, gerando mudanças rápidas e intensas nas oportunidades de acesso institucional (tanto em termos de grau quanto em termos de forma). Especificamente no caso das relações entre organizações sociais e o governo Lula, Hochstetler (2008, p.44) destaca que

\begin{abstract}
A inclusão mais sistemática das Organizações da Sociedade Civil [OSCs] veio na forma como o Governo Lula compôs a administração nacional. Líderes de OSCs de todos os tipos agora trabalham dentro do governo em questões que eles
\end{abstract}

\footnotetext{
13 A importância do partido político na configuração dessa permeabilidade pode ser observada, nos casos de governos de coalizão como os de Lula e Dilma, a partir das variações das oportunidades de acesso a diferentes setores do governo/Estado controlados por forças políticas partidárias distintas. Nesse sentido, enquanto alguns setores do Governo Lula eram considerados altamente permeáveis por certas organizações de movimentos sociais, outros eram avaliados como totalmente impermeáveis e, logo, adversários. Essa complexidade pode ser claramente observada nas relações muito diferenciadas de organizações como o Movimento dos Sem-Terra ou o Movimento dos Pequenos Agricultores com o Ministério de Desenvolvimento Agrário (altamente permeável aos seus interesses) e o Ministério da Agricultura (muito mais permeável aos interesses dos denominados "ruralistas" ou do "agronegócio").
} 
anteriormente tentavam influenciar de fora. Líderes da CUT se viram no lado do governo nas negociações salariais em nove Ministérios, 53 Secretarias e centenas de posições de segundo e terceiro escalões (...). Outros exemplos incluem o primeiro Presidente do Incra, que tinha fortes ligações com o Movimento dos Sem-Terra, e a Ministra do Meio Ambiente Marina Silva, que cresceu em comunidades de seringueiros na Amazônia e tinha anos de credibilidade como uma ativista ambiental e legisladora. Este é um padrão de recrutamento familiar das primeiras administrações do PT (...). Eles lativistas das OSCs] estão perto dos centros de poder e são capazes de tomar decisões, mas também se encontram limitados por constrangimentos orçamentários e burocráticos que frequentemente os afastam daqueles que ainda estão fora do Estado.

Essa ênfase na centralidade do trânsito institucional como mecanismo de permeabilidade entre movimentos sociais e Estado, conformando um quadro de expressiva intersecção Estado-Movimentos, parece ser um argumento analiticamente fértil para romper com abordagens simplistas que ignoram as complexas relações estabelecidas entre organizações sociais, partidos e Estado, as quais se produzem no Brasil, em grande parte, através do deslocamento e compartilhamento de seus integrantes. É esse tipo de relação, caracterizada pelo intenso trânsito de atores entre as organizações sociais e o Estado e pela alta intersecção, que está presente na constituição do que é denominado de Movimento de Economia Solidária.

\section{A Economia Solidária: breve apresentação}

O termo Economia Solidária (ES) surge na década de 1990 como uma definição para as iniciativas de trabalhadores, produtores e consumidores de diversas atividades econômicas que passam a se organizar segundo princípios de cooperação, autonomia e gestão democrática. Economia Solidária passa a ser, então, uma denominação amplamente utilizada em vários continentes, sob diversas acepções teóricas, mas que, 
genericamente, abrange práticas econômicas baseadas na ideia de solidariedade, em contraste ao individualismo utilitarista (Laville e Gaiger, 2009, p. 169).

A ES - enquanto proposta normativa - defende a construção de um modelo econômico baseado em relação igualitárias, calcado na eliminação da exploração e das desigualdades decorrentes das práticas de trabalho mediadas por vínculos de propriedade. Em um empreendimento de ES, o objetivo deve ser o estabelecimento de relações simétricas entre seus associados, através da implantação de um processo de autogestão que garanta a todos o direito de participar de forma equânime da gestão e dos resultados do empreendimento econômico.

Boa parte dos pesquisadores identifica a origem da ES no cooperativismo clássico do século 19. Ela seria herdeira de iniciativas como a de socialistas utópicos (Owen, Fourier e Blanc), os quais constituíram iniciativas econômicas autônomas (geralmente comunais) visando à organização de espaços de trabalho descentralizados e cooperativos. Além dessas iniciativas, diversos estudiosos evocam como marco fundador da ES a experiência vivida na cidade inglesa de Rochdale, em 1844 (Singer e Souza, 2000; Laville e Gaiger, 2009). Naquele ano, trabalhadores desempregados fundaram um empreendimento cooperativo com o objetivo de criar uma comunidade que oferecesse autossuficiência aos seus membros.

Ainda que a comparação entre as experiências cooperativas do século 19 e a ES do final do século 20 seja alvo de controvérsias, o "ressurgimento" de um cooperativismo político-contestador é explicado pela literatura como decorrente das lutas por alternativas às intensas transformações que impactaram as relações de trabalho a partir da década de 1970.

Esse período foi marcado pela crise do modelo fordista-taylorista de produção (Harvey, 1996) e, como resultado, observou-se o crescimento do desemprego em praticamente todo o mundo, agravado ainda pelas dificul- 
dades de financiamento do Estado de Bem-Estar Social na Europa Ocidental e pela adoção de políticas econômicas inspiradas no neoliberalismo em boa parte dos países ocidentais, incluindo países latino-americanos.

É nesse contexto que a ES ganha espaço, primeiramente na França (sob denominação de Economia Social) e, posteriormente, como experiência concreta na América Latina e no restante da Europa (Lechat, 2002). No Brasil, as primeiras iniciativas de projetos econômicos populares - que, nos anos 1990, passaram a ser identificados como pioneiros da ES no país - datam da década 1970, através das iniciativas da Cáritas (setor da Igreja Católica que está presente em diversos países e tem como um de seus objetivos prestar assistência e apoio a iniciativas de desenvolvimento comunitário).

A partir da década de 1990, observa-se uma expansão expressiva de diversas iniciativas econômicas identificadas sob a denominação de ES, como a recuperação da massa falida de empresas que passam para o controle dos trabalhadores, práticas cooperativas adotadas pelo Movimento dos Trabalhadores Rurais Sem-Terra (MST) em seus assentamentos e diversas outras manifestações comunitárias, geralmente voltadas à produção de alimentos e ao artesanato na zona rural e nas periferias dos grandes centros urbanos.

O processo de constituição da ES tem congregado uma gama diversa de organizações e instituições, cujo propósito tem sido superar os imperativos que obstacularizam a consolidação dessa outra esfera de relações econômicas (como as dificuldades de inserção e competição no mercado capitalista, por exemplo). No Brasil, o chamado Movimento da Economia Solidária é composto basicamente pelos seguintes atores: 
Figura 2: O campo da Economia Solidária no Brasil

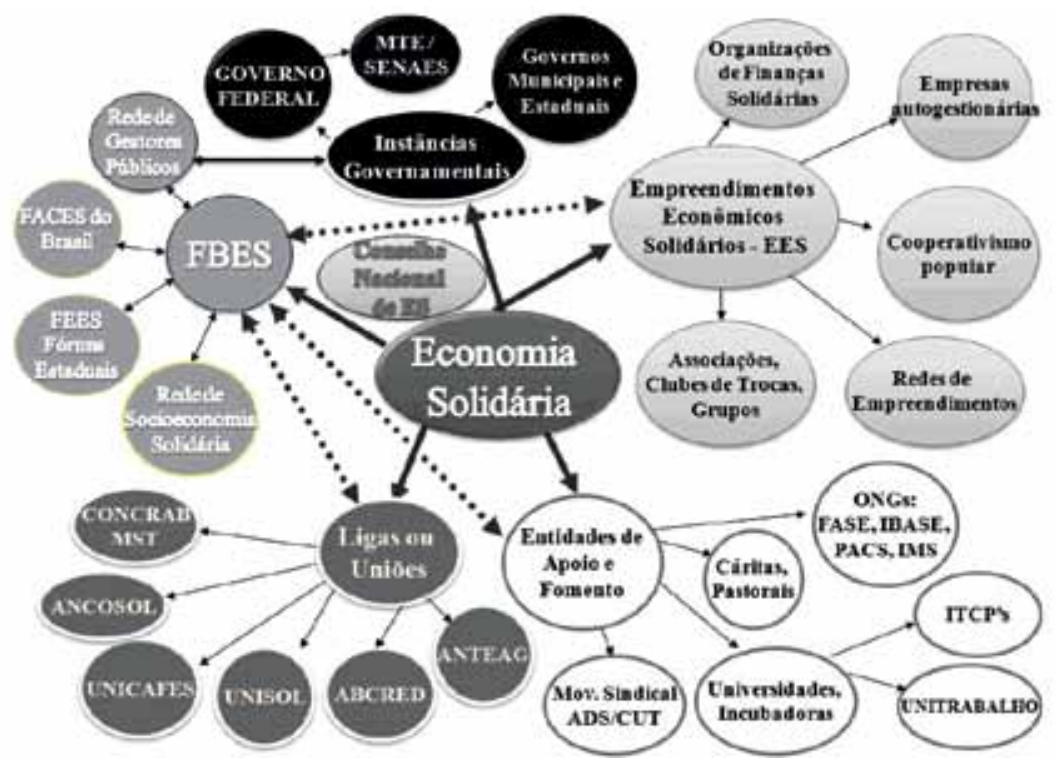

Fonte: SIES, 2005

Podemos perceber, a partir da figura acima, que há uma multiplicidade de organizações, instâncias e atores compondo o que é denominado como Movimento de Economia Solidária no Brasil. Nessa rede, agentes e instituições estatais desempenham papel de grande influência, conformando - juntamente com as organizações sociais - um dos elementos estruturantes do movimento ${ }^{14}$.

14 Um fato que suscita discussões sobre a definição da ES como movimento social unívoco ou não, um setor distinto de atividades, ou simplesmente como práticas econômicas de caráter cooperativo é o fato de outros movimentos sociais, com bandeiras, pautas e demandas das mais diversas, incorporarem em seus programas práticas que aludem à ES, como é o caso do MST, do movimento ambientalista, do movimento quilombola e do movimento de trabalhadores desempregados, por exemplo. 
Dentre as principais organizações que compõem o Movimento de Economia Solidária e que geralmente operam como fomentadoras e articuladoras de empreendimentos de economia solidária (EES), temos diversas ONGs, as Incubadoras Tecnológicas de Cooperativas Populares (ITCPs) - geralmente vinculadas a universidades e governos -, a Central Única dos Trabalhadores (CUT), ligas e entidades representativas de empreendimentos, partidos políticos (PT) e entidades religiosas, como a Cáritas.

A extensa gama de atores inseridos nesse campo de práticas resulta na formação de uma complexa e extensa trama de agentes que representam interesses e utilizam práticas diversas, mas que se identificam enquanto componentes de uma mesma rede em defesa da ES. É interessante observar a maneira como estão articuladas as organizações civis e as instituições estatais, cuja mediação se dá, basicamente, através dos fóruns deliberativos (o Fórum Brasileiro de Economia Solidária - FBES - como organização civil, juntamente com suas seções estaduais, regionais e municipais, e o Conselho Nacional de Economia Solidária - CNES - como instância deliberativa institucional).

As relações institucionais da ES em nível federal se intensificaram com a eleição de Lula em 2003 e a criação, no mesmo ano, da Secretaria Nacional de Economia Solidária (SENAES), vinculada ao Ministério do Trabalho e Emprego e responsável pela formulação de políticas públicas para a ES em todo o país. Como veremos adiante, a chegada do PT ao governo federal, ao governo estadual no Rio Grande do Sul e à Prefeitura Municipal de Porto Alegre (PMPA) representou para o Movimento de Economia Solidária do Rio Grande do Sul a abertura de oportunidades que intensificaram as relações de intersecção entre Movimento-Estado, mediadas por vinculações político-partidárias. 


\section{Procedimentos metodológicos da pesquisa}

Buscando constituir uma base empírica que desse sustentação ao argumento teórico que orienta este artigo, realizou-se uma reconstituição das trajetórias de onze militantes que, ao longo do tempo, atuaram tanto nas organizações sociais da ES (empreendimentos econômicos solidários, ONGs, entidades de apoio e fomento) quanto na gestão pública, através da ocupação de cargos em setores relacionados às políticas públicas para a ES na Prefeitura de Porto Alegre e no governo do Estado do Rio Grande do Sul ${ }^{15}$. Além disso, foram realizadas entrevistas temáticas com quatro indivíduos (um membro de empreendimento, um membro de entidade religiosa e dois pesquisadores do tema) que mantêm um vínculo orgânico com o Movimento de Economia Solidária.

Dessa forma, procuramos captar as distintas visões sobre o processo de consolidação da ES no Estado do Rio Grande do Sul, desde os principais atores que constituem o movimento. Na tabela seguinte, apresentamos a relação de entrevistados, aos quais foram atribuídos nomes fictícios:

15 A busca de entrevistados que expressassem nas suas trajetórias o mecanismo de trânsito institucional e a interpenetração entre movimento e partido possibilitou, por um lado, mostrar a pertinência do modelo de análise proposto. Por outro lado, no entanto, ela define um critério de seletividade que restringe o poder de generalização na análise, uma vez que foca indivíduos cujas características e trajetórias não podem ser universalizadas para o conjunto do Movimento de Economia Solidária. 
Tabela 1. Quadro de entrevistados

\begin{tabular}{|c|c|c|}
\hline & Nome & Atributos \\
\hline E1 & Álvaro & $\begin{array}{l}\text { Considerado o principal formulador das primeiras políticas de econo- } \\
\text { mia solidária da PMPA. Integrou o governo estadual e teve ligação com } \\
\text { a ES através da atuação em ONGs. Atualmente é professor de História, } \\
\text { trabalha em um empreendimento de ES. }\end{array}$ \\
\hline E2 & Igor & $\begin{array}{l}\text { Trabalhou junto com Álvaro na formulação das primeiras políticas de ES } \\
\text { em Porto Alegre. Teve rápida passagem pelo governo estadual e atuou } \\
\text { na rede de ES também através de ONGs. Atualmente, trabalha no MDA. }\end{array}$ \\
\hline E3 & Cézar & $\begin{array}{l}\text { Foi chefe de gabinete da SEDAI durante o governo estadual e atual- } \\
\text { mente está ligado a uma ONG que executa projetos de ES. }\end{array}$ \\
\hline E4 & Pedro & $\begin{array}{l}\text { Cursou mestrado em Sociologia tendo como tema de pesquisa a ES. } \\
\text { Atualmente, faz doutorado na mesma área, no qual pesquisa a ES. } \\
\text { Teve participação nas políticas públicas do governo estadual e na pre- } \\
\text { feitura de uma cidade da região metropolitana de Porto Alegre. }\end{array}$ \\
\hline E5 & Lucas & $\begin{array}{l}\text { Presidiu uma associação de artesãos no sul do Estado, onde foi convi- } \\
\text { dado para coordenar as políticas de ES de um município. Coordenou } \\
\text { projetos da SENAES no Rio Grande do Sul e atualmente trabalha na } \\
\text { constituição de um empreendimento ES. }\end{array}$ \\
\hline E6 & Miguel & $\begin{array}{l}\text { Atuou como gestor público nas políticas da PMPA e teve breve participa- } \\
\text { ção no governo estadual. Atualmente, coordena uma ONG ligada à ES. }\end{array}$ \\
\hline E7 & Júlio & $\begin{array}{l}\text { Trabalhou em um EES e teve participação nas políticas públicas da PMPA } \\
\text { e do governo estadual como educador. Atualmente, atua como gestor } \\
\text { público de ES em um município da região metropolitana de Porto Alegre. }\end{array}$ \\
\hline E8 & Juliano & Sindicalista com atuação nas políticas públicas de ES da PMPA. \\
\hline E9 & Cláudio & $\begin{array}{l}\text { Atuou por um breve período no governo estadual, dedicando a maior } \\
\text { parte de seu trabalho na ES através de ONGs. }\end{array}$ \\
\hline E10 & Fabiano & $\begin{array}{l}\text { Trabalhou como educador popular nas políticas públicas de ES da } \\
\text { PMPA e teve breve passagem pela SEDAI durante o governo do Estado. }\end{array}$ \\
\hline E11 & João & $\begin{array}{l}\text { Sindicalista com experiência de trabalho na gestão pública do governo } \\
\text { estadual. Atualmente, compõe os quadros da SENAES. }\end{array}$ \\
\hline E12 & Nádia & Trabalhadora de uma cooperativa de ES. \\
\hline E13 & Marina & Integrante da Cáritas Diocesana. \\
\hline E14 & Gil & Sociólogo com afinidade de pesquisa em ES. \\
\hline E15 & Gabriel & Sociólogo especialista em economia solidária. \\
\hline
\end{tabular}


Através da reconstituição das trajetórias dos onze militantes-gestores e das informações obtidas junto aos outros entrevistados, busca-se apreender a forma como se estruturam as relações entre organizações sociais e Estado, tendo por referência a experiência do Estado do Rio Grande do Sul. Mais especificamente, as trajetórias são utilizadas como instrumento metodológico para apreensão de como se dá a permeabilidade do campo político institucional pelos atores oriundos da sociedade civil e vice-versa.

\section{Trânsito institucional e permeabilidade na Economia Solidária}

Apesar da existência de experiências prévias de projetos econômicos populares e/ou alternativos, como as experiências da Cáritas referidas anteriormente, é no início dos anos 90 que se pode falar propriamente de um Movimento de Economia Solidária. Tal movimento, por sua vez, se constituiu a partir de iniciativas de organizações e movimentos sociais (entidades representativas de empreendimentos, ONGs, sindicatos, MST, organizações comunitárias etc.), mas também contou com a presença ativa de agentes posicionados no interior do aparelho estatal desde seus primórdios. ${ }^{16}$

Nesse sentido, as primeiras políticas públicas implementadas pela Prefeitura de Porto Alegre sob os governos petistas, entre meados da década de 1990 e 2004, foram não apenas uma resposta às demandas das organizações constitutivas do Movimento de Economia Solidária, mas também ações marcadas pela intencionalidade de incentivar - e, no limite, in-

16 O significativo acesso do Movimento de Economia Solidária ao Estado brasileiro, particularmente naquelas parcelas governadas pelo PT, parece ser um elemento importante para explicar as profundas diferenças em termos de repertórios de ação entre este movimento no Brasil e na Argentina. Neste último país, conforme expresso no Documentário The Take (Avi Lewis, Canadá, 2004), se observa um nível muito maior de conflitualidade e a presença de repertórios fortemente marcados pela ação direta confrontacional. Mesmo que esses elementos não estejam ausentes no Brasil, os repertórios de ação do Movimento de Economia Solidária apresentam-se muito mais institucionalizados. 
duzir - a criação de tal movimento ${ }^{17}$. Da mesma forma, as políticas e ações do governo do Estado do Rio Grande do Sul na gestão de Olívio Dutra (PT - 1999-2002) também tiveram o claro sentido de criar condições tanto para a viabilidade econômica dos empreendimentos de $\mathrm{ES}^{18}$ quanto para o processo de articulação e ação coletiva das organizações constitutivas do movimento, tal como relatado por alguns dos entrevistados:

Na minha opinião, desde aquela época, (...) tinha mais uma organização estruturada mesmo em torno da Igreja, em torno da Cáritas, né? Fóruns não existiam. Acho que havia uma iniciativa em torno da prefeitura de Porto Alegre, que daí fomenta o público. Identifica, fomenta, organiza e aí o Fórum vai ter um reflexo pra fora do Estado (....). Parece diferente aqui: normalmente tu tem a ideia tradicional de que primeiro há uma organização social, que ela demanda e o Estado reage. Talvez na ES nós temos uma relação inversa, tá? Existia um público fragmentado, disperso. Existia um sujeito social, que talvez a sua autoidentidade era ainda muito dispersa. E o fomento estatal da política pública cria condições para a auto-organização.(Cézar)

Uma peculiaridade do movimento de ES é essa vinculação que ele tem com o Estado, em relação a outros. Por mais que tu queiras comparar tu não vai encontrar em outros movimentos (...). Quando tu cria um movimento onde os próprios gestores se consideram parte do movimento, como é o caso da $E S$, é uma coisa que é um diferencial. E essa relação é uma relação muito forte, né? Tanto é que até hoje o fórum

17 As condições de possibilidade desse pioneirismo da Prefeitura de Porto Alegre e do Governo do Rio Grande do Sul na indução da ES (e, particularmente, a apropriação desse tema por certas correntes internas do PT gaúcho) não foram objeto deste estudo e constituem um tópico interessante para futuras análises. As entrevistas permitem observar, no entanto, a ação de certos segmentos do PT, vinculados ou não à ES, que identificam nessa questão um elemento estratégico para um processo de transformação político-social e, ao mesmo tempo, para oferecer alternativas concretas à reprodução social de segmentos atingidos pelo desemprego e/ou excluídos do mercado de trabalho formal.

18 De acordo com dados do Departamento de Economia Popular Solidária, criado durante o período em que o PT esteve à frente do governo do Estado do Rio Grande do Sul, foram destinados aproximadamente $R \$ 12$ milhões em linhas de crédito para empreendimentos de Economia Solidária (DEPSOL, 2002). 
tem essa dependência. Como, por exemplo, depois que saiu a Prefeitura [derrota do PT na Prefeitura de Porto Alegre] o movimento decaiu. Ele tinha muita dependência do governo. Foi muito mais o Estado, fomentando a existência daquele setor, do que algo que venha de baixo pra cima.(Pedro).

Hoje, eu acho que essa bandeira [da ES] é galvanizada pelo setor público. No momento em que ele levanta a bandeira, levanta as políticas e aí o movimento se agrega à volta.(Álvaro)

A partir das políticas públicas destinadas à Economia Solidária, as quais têm continuidade e ampliação com a criação da Secretaria Nacional de Economia Solidária (SENAES) a partir da chegada do PT à Presidência da República em 2003, observa-se uma proliferação quantitativa de empreendimentos de $\mathrm{ES}^{19}$, que se expressa nos dados do gráfico a seguir

Gráfico 1. Fundação dos empreendimentos de ES atualmente existentes no Brasil - quantidade por década ${ }^{20}$

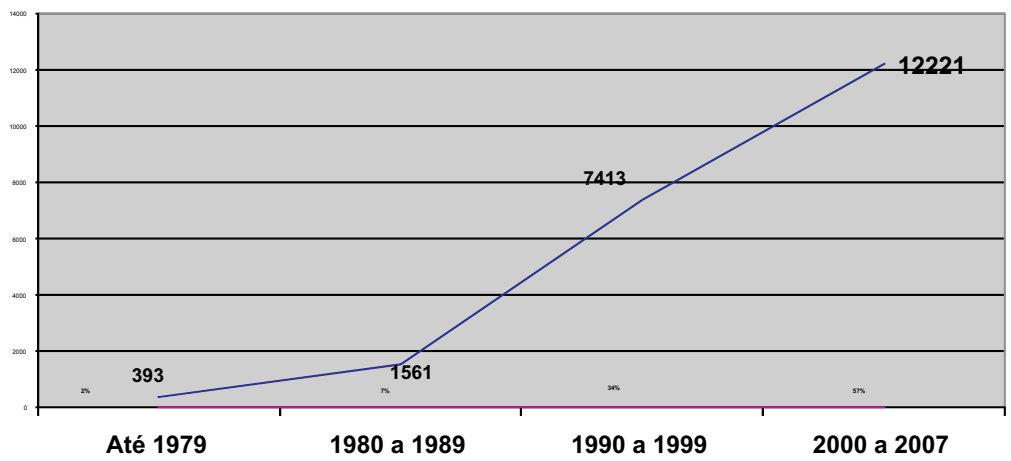

Fonte: SIES

19 Dados quantitativos relativos ao crescimento da economia solidária ao longo das últimas décadas podem ser acessados no sítio do Sistema Nacional de Informações em Economia Solidária (SIES), cujo endereço eletrônico é o seguinte: http://www.mte.gov.br/ecosolidaria/sies.asp

20 Os dados acima se referem à quantidade de empreendimentos atualmente existentes no Brasil, fundados por década. Por isso, não servem para ilustrar uma evolução quantitativa linear dos empreendimentos de ES ao longo do tempo. Todavia, esses são os únicos dados disponibilizados pelo SIES que permitem algum tipo de aproximação com a expansão das experiências de economia solidária nas últimas décadas. Isso acontece porque o primeiro levantamento de 
De acordo com a argumentação apresentada neste artigo, essa abertura à ES observada em diferentes governos petistas em distintos níveis (municipal, estadual e federal) se deve menos à existência de uma mobilização social conflitiva de atores excluídos da política institucional, conforme a visão tradicional sobre a relação entre movimentos sociais e Estado, e mais à presença de um expressivo acesso das organizações do Movimento de Economia Solidária aos espaços institucionais nos quais foram/ são construídas as políticas e ações governamentais direcionadas à ES. Tal acesso, por sua vez, se dá, em grande medida, pelo trânsito constante de militantes do Movimento de Economia Solidária entre posições nas organizações sociais e na gestão pública; trânsito este viabilizado, entre outros aspectos, por um pertencimento partidário (PT) comum e generalizado.

A sustentabilidade empírica desse argumento é demonstrada, primeiramente, quando se observam os dados sobre os principais espaços que possibilitaram a inserção dos entrevistados no Movimento de Economia Solidária contidos no quadro a seguir:

dados sobre a ES em escala nacional ainda é muito recente (2005), o que possibilitou contato somente com os empreendimentos ainda existentes, não havendo até então informações sobre os empreendimentos que deixaram de existir ao longo desse período. Todavia, podemos perceber que dos empreendimentos atualmente existentes no Brasil, boa parte deles surgiu, sobretudo, nas décadas de 1990 e 2000, períodos em que são implementadas as primeiras políticas públicas para a economia solidária no país (nos níveis municipal, estadual e federal). 
Quadro 1. Principais espaços de inserção, atuação militante e contato com a economia solidária ${ }^{21}$

\begin{tabular}{|c|c|c|c|c|c|c|c|c|c|c|}
\hline & 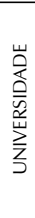 & 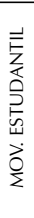 & $\begin{array}{l}\frac{a}{\Sigma} \\
\vdots \\
0 \\
0 \\
0 \\
0 \\
\frac{1}{2}\end{array}$ & 㞯 & $\begin{array}{l}\vdots \\
\stackrel{0}{0} \\
.1\end{array}$ & U & 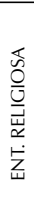 & 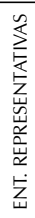 & $\begin{array}{l}\frac{O}{k} \\
\frac{\mathfrak{U}}{\vdots} \\
\frac{Z}{n}\end{array}$ & 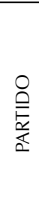 \\
\hline E1 & & & & & & & & & & \\
\hline E2 & & & & & & & & & & \\
\hline E3 & & & & & & & & & & \\
\hline E4 & & & & & & & & & & \\
\hline E5 & & & & & & & & & & \\
\hline E6 & & & & & & & & & & \\
\hline E7 & & & & & & & & & & \\
\hline E8 & & & & & & & & & & \\
\hline E9 & & & & & & & & & & \\
\hline E10 & & & & & & & & & & \\
\hline E11 & & & & & & & & & & \\
\hline
\end{tabular}

Fonte: elaboração própria.

21 Os espaços contidos nas colunas indicam, respectivamente: universidade, movimento estudantil, movimento popular, empreendimentos de economia solidária (EES), fóruns de representação, organizações não governamentais (ONG), entidades religiosas, entidades representativas de empreendimentos, centrais sindicais e partido político. As células preenchidas com a cor cinza indicam a inserção do indivíduo em determinado espaço, entidade ou instituição, enquanto as células em branco indicam ausência de inserção. 
Um primeiro aspecto que se destaca nos dados do quadro anterior é a expressiva presença da militância múltipla entre os entrevistados. Nesse sentido, observa-se que não há nenhum caso de inserção/atuação em apenas um espaço. Ao contrário, há uma clara predominância de participação em diferentes instituições/organizações, se destacando os entrevistados com quatro (três casos) e cinco (quatro casos) inserções.

Em segundo lugar, os dados do quadro apontam a centralidade do partido político (e, mais especificamente, do PT) entre os militantes da ES entrevistados, elemento comum a todas as trajetórias reconstituídas. Essa forte interpenetração entre o Movimento de Economia Solidária e o PT se expressa no fato de que esse é o único partido brasileiro que apresenta, há mais de uma década, Programas de Governo com propostas de políticas públicas voltadas para o fortalecimento da ES. Tal interpenetração tende a criar uma relação de reforço circular, na medida em que os agentes da ES identificam o PT como um partido permeável aos seus interesses e demandas e os petistas reconhecem o fortalecimento da ES como um compromisso do partido (no limite, a ES se transforma em uma proposta do PT, que é visto como o partido comprometido com a ES).

De acordo com as entrevistas realizadas, pode ser constatado que existem dois percursos básicos entre os entrevistados: de um lado, encontram-se quatro entrevistados (E2, E4, E5 e E6) que tiveram primeiramente uma atuação no partido e, a partir desta, entraram em contato e passaram a atuar na ES; de outro lado, estão os outros sete entrevistados (E1, E3, E7, E8, E9, E10 e E11) que iniciaram sua atuação na ES a partir da inserção em outras organizações ou instituições e, posteriormente, se filiam ao partido político e se inserem na vida partidária.

Outro aspecto que se destaca no quadro anterior é a importância da Universidade na trajetória dos entrevistados. De fato, depois do partido político, a Universidade é o segundo espaço de atuação mais recorrente, presente na trajetória de oito dos onze entrevistados. Essa relevância da 
Universidade (que indica um alto nível de escolaridade entre a maior parte dos entrevistados) se constitui em um importante indicador da seletividade existente no trânsito institucional, apontando que, para adentrar no Estado e ocupar posições na gestão, tende a ser necessário possuir certos atributos como escolaridade elevada.

A identificação dessa seletividade no trânsito institucional ajuda a explicar a limitada presença entre os entrevistados de indivíduos com atuação iniciada no movimento popular e comunitário (apenas E7 e E8) ou em empreendimentos (somente E7), os quais tendem a ser indivíduos oriundos de classes sociais menos favorecidas e com menor acesso à educação formal. Esses dois entrevistados iniciaram suas trajetórias em associações vinculadas ao trabalho de base da Igreja Católica, que no Brasil tem presença marcante em espaços sociais populares. Nesse sentido, observa-se que, apesar do Movimento de Economia Solidária ter suas principais bases entre os segmentos de baixas renda e escolaridade, o trânsito institucional tende a estar "reservado" para indivíduos dotados de certos recursos (em especial, o capital escolar).

Outra informação obtida nas entrevistas e que merece destaque é o fato de somente três entrevistados terem relatado relação direta de trabaIho com empreendimentos de ES; ou seja, somente E1, E5 e E7 já foram ou são atualmente trabalhadores de cooperativas de ES. Dentre eles, Júlio (E7) é o único que passou a conhecer a ES a partir do trabalho como associado em um empreendimento que lhe foi uma alternativa ao desemprego. Lucas (E5), por sua vez, constituiu uma cooperativa de comunicadores responsáveis por veicular e difundir informações sobre ES após suas experiências como gestor. Da mesma forma, Álvaro (E1) constituiu um empreendimento responsável por articular compras coletivas de produtos provenientes da ES após desvincular-se da gestão pública.

Essas informações são importantes na medida em que apreendem um percurso pouco explorado nas análises sobre trajetórias militantes no Brasil: 
estas tendem a abordar um percurso que vai das organizações sociais, nas quais são geradas e/ou acumuladas certas capacidades e recursos, para as instituições do Estado; nos casos de Lucas e Álvaro, no entanto, percebe-se que a inserção na gestão pública também pode ser vista como uma etapa que possibilita aos indivíduos determinados acúmulos que contribuem para - e, mesmo, viabilizam - uma inserção associativa posterior.

As ONGs também são entidades com presença muito forte na constituição do Movimento de Economia Solidária, através da captação de recursos e/ou da execução de projetos junto a governos. Cinco dos nossos entrevistados (E1, E2, E3, E6 e E9) já trabalharam com ES atuando em ONGs, sendo que Cláudio (E9) teve seu primeiro contato com a ES a partir de um longo período de trabalho em uma organização não-governamental. Já Miguel (E6) constituiu uma ONG juntamente com Cézar (E3), após abandonar a gestão pública, na qual trabalham atualmente. Aqui, da mesma forma que na relação entre empreendimentos e gestão, observa-se um percurso de mão dupla, com deslocamentos das ONGs para a gestão pública e vice-versa.

O último espaço significativo de atuação entre os entrevistados ocorre no âmbito dos fóruns da ES, nos quais E4, E5, E7, E9 e E10 tiveram participação ativa. Pedro (E4), Júlio (E7) e Fabiano (E10) atuaram no Fórum Metropolitano de Economia Solidária e no Fórum Gaúcho de Economia Solidária como representantes da Rede de Gestores de Economia Solidária. Lucas (E5) e Cláudio (E9), por sua vez, atuam nesses fóruns a partir de entidades representativas e ONGs, respectivamente, principalmente na articulação dos empreendimentos e suas entidades na discussão e proposição de políticas públicas.

$\mathrm{Na}$ figura a seguir, apresenta-se um esquema que ilustra o posicionamento típico dos entrevistados, situando-os na intersecção entre organizações do Movimento de Economia Solidária e a esfera estatal, que eles conectam através do seu trânsito institucional: 
Figura 3. Posicionamento dos militantes-gestores nas esferas civil e estatal

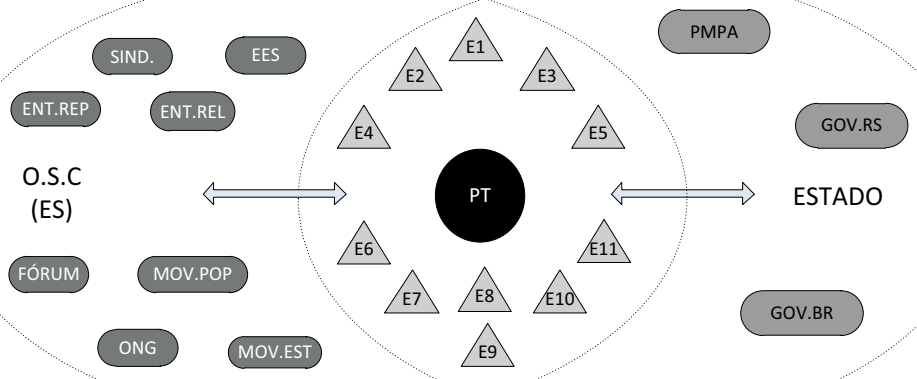

Fonte: elaboração própria.

Esse esquema tem por objetivo não somente demonstrar a centralidade do partido na mediação entre sociedade civil e Estado, mas também ilustrar como a atuação dos entrevistados nas organizações sociais e na esfera estatal (via partido) acaba por "nublar" determinadas fronteiras institucionais. A capacidade de ocupar espaços na sociedade civil e no Estado caracteriza nossos entrevistados como militantes-gestores, os quais representam, através de suas trajetórias, uma interpenetração entre partido e movimento, que é a condição de possibilidade do trânsito institucional observado na pesquisa.

Assim, o envolvimento partidário, ao contrário de um "problema", representa uma possibilidade efetiva de inserção no Estado através da ocupação de posições na gestão pública, tornando o Estado permeável às propostas e demandas do Movimento de Economia Solidária. Dessa forma, em contextos nos quais haja essa alternativa, a atuação partidária constitui uma das possibilidades de ação das organizações e dos movimentos sociais no sentido de ampliação de suas capacidades de apropria- 
ção institucional ${ }^{22}$. Nesse sentido, a intersecção entre Estado e movimento - traduzida nas trajetórias de militância múltipla dos entrevistados - vem a ser uma estratégia frutífera para determinados setores movimentalistas, tal como manifestado nos seguintes relatos extraídos das entrevistas:

Os gestores públicos todos, quem estava à frente da política pública do governo do Estado [do Rio Grande do Sul], era gente que era do movimento sindical antes de ir pra lá, que depois passam pra ES (..). Todos saem e têm uma origem ou da Igreja, ou do sindicato, ou da universidade, ou do partido. Então existe essa vinculação dos setores públicos que ocupam o Estado pra realizar essas políticas. (Pedro)

Tenho observado, desde que comecei a participar do movimento, que esta é uma lógica da ES nesse processo. Aquelas pessoas que são liderança, que são referência dentro dos movimentos lá na sociedade civil, ou no empreendimento, ou numa ONG e que têm acúmulo, a gestão pública tem feito isso, tem se pautado dessa forma, de trazer para os espaços institucionais pessoas com acúmulo. Porque é um tema novo, é uma coisa que nem toda a gestão pública domina ainda. A gente tem que ter alguém que opere isso, que comece a fomentar isso. E quem são essas pessoas? São pessoas que vêm da base e que têm acúmulo. (Júlio)

Os CCs [Cargos de Confiança] que ocupam hoje parte do Estado (...) eles vêm de algum lugar, são militantes dos sindicatos, do movimento popular, partidários e tal. E hoje acho que há uma compreensão dessa esquerda não ortodoxa de que a Economia Solidária merece uma atenção e o Estado deve apoiar isso. O Estado apoia com financiamento, com assistência técnica, com incentivo e com uma série de coisas a economia privada. Por que não pode apoiar a Economia Solidária? (...) Então, que bom que essas pessoas, esses

22 Tarrow (2001, p.15) define o mecanismo de apropriação institucional como o uso, por determinados grupos ou organizações, "dos recursos ou reputação de uma instituição para servir aos seus propósitos". 
militantes que estão indo para o Estado e que vêm de outros espaços, já entram no Estado com essas preocupações daquele meio de onde vêm. Eu imagino que essas políticas devem ser fortalecidas. (Juliano)

Dando continuidade à análise, no gráfico seguinte apresentamos a participação de cada entrevistado em diferentes governos (Prefeitura de Porto Alegre, Governo do Estado do Rio Grande do Sul e Governo Federal) que implantaram políticas públicas para a ES:

Gráfico 2. Inserção e duração das trajetórias individuais no recorte temporal das políticas públicas

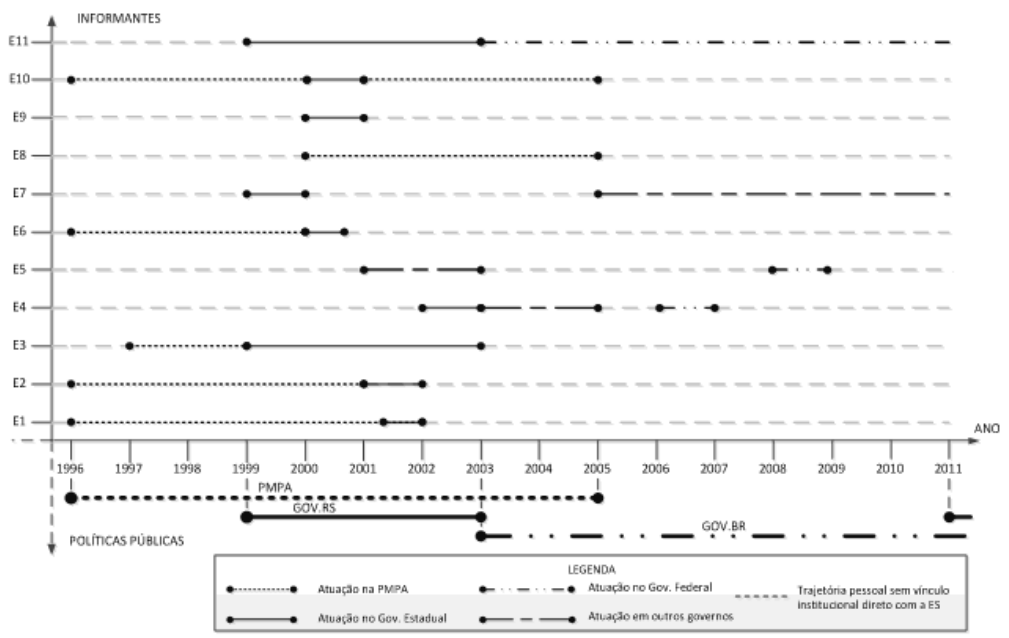

Fonte: elaboração própria.

Ao analisar esse gráfico, pode-se perceber que em sete das onze trajetórias representadas, há passagem direta de uma experiência de governo para outra e, em duas dessas sete trajetórias (E4 e E11), há movimentação de um nível para outro logo após o fim de determinada gestão pública - 
ocasionada por derrota eleitoral. Nesse sentido, observa-se que o trânsito dos entrevistados de uma esfera de governo para outra é comum, tendo somente dois deles (E8 e E9) atuado em apenas uma gestão. A presença de cinco trajetórias (E1, E2, E3, E6 e E10) que passam diretamente da PMPA para o Governo do Estado é explicada pela demanda de pessoal solicitada à época para execução de políticas em nível estadual, o que provocou o deslocamento de boa parte dos quadros de uma instância para outra.

Esse trânsito intenso entre diferentes esferas de governo é possibilitado, de um lado, pelo acúmulo de capacidades e recursos que as experiências prévias no Movimento de Economia Solidária e, sobretudo, na gestão pública fornecem aos entrevistados. De outro lado, esse trânsito também se assenta na filiação dos entrevistados ao partido (PT), a qual viabiliza que estes possam participar da concorrência acirrada pelos cargos de gestão passíveis de serem apropriados pelo partido.

Portanto, o partido desempenha um papel central nesta intersecção Movimento-Estado, justamente por ser o elemento mediador entre as duas esferas e, particularmente, por possibilitar que seus filiados vinculados ao Movimento de Economia Solidária acessem diretamente posições de gestão em casos de vitória eleitoral. Assim, a permeabilidade de parcelas e setores do Estado brasileiro a demandas do Movimento de Economia Solidária é explicada, em grande medida, pela "porta de entrada" aberta pelo partido a indivíduos oriundos de diversas organizações e instituições sociais, seja através da concessão de cargos de confiança, seja pela própria militância partidária concomitante à atuação em organizações do movimento.

\section{Considerações finais}

A análise das trajetórias dos militantes da ES ilustra, de forma contundente, a presença de um padrão de relação entre movimento e Estado 
que se afasta profundamente da interpretação dessa relação construída e generalizada a partir dos movimentos que emergiram no processo da redemocratização. De um lado, ao contrário de uma exterioridade em relação ao campo político-administrativo, observa-se uma intersecção profunda entre movimentos e Estado que, no limite, pode ser apontada como uma condição de possibilidade da própria constituição do Movimento de Economia Solidária tal como ele se apresenta. De outro lado, através do trânsito institucional mediado pelo pertencimento partidário, conforma-se um processo constante de deslocamento entre posições nas organizações do Movimento de Economia Solidária e posições na gestão pública que produzem uma relativa diluição das fronteiras institucionais.

Como salientado por um entrevistado anteriormente, talvez esse seja um padrão particular do Movimento de Economia Solidária, não devendo ser generalizado para o conjunto dos movimentos sociais brasileiros. Mesmo reconhecendo a importância de evitar tal tipo de generalização, o caso pesquisado parece relevante por mostrar, em um grau mais intenso, formas de relação entre organizações de movimentos sociais e Estado no Brasil que têm sido relativamente negligenciadas pela literatura nacional.

Pesquisas realizadas em outros setores de políticas públicas - como a Saúde (Weyland, 1996; Falletti, 2010), o Meio Ambiente (Barcelos, 2010; Losekann, 2009) e a Agricultura Familiar (Muller, Silva e Schneider, 2007) - mostram que a "infiltração do Estado" pelas organizações de movimentos sociais e/ou seus aliados é um mecanismo recorrente e de fundamental importância tanto na compreensão da forma como tais organizações atuam quanto nos efeitos que produzem.

Assim, casos como o brasileiro, cujo Estado, nos seus diversos setores e níveis, apresenta profundas diferenças em termos das relações que estabelece com os atores da sociedade civil, parecem oferecer um campo empírico fértil para análises comparativas (intranacionais e internacionais) 
sobre como distintos graus de inclusão/exclusão institucional incidem nos processos de organização e atuação dos movimentos sociais.

Além disso, as presenças marcantes da interpenetração entre organizações de movimentos sociais e partidos políticos e, em certas conjunturas, de um intenso trânsito institucional (gerando um quadro de intersecção Estado-Movimentos) oferecem um processo contrastante frente àqueles de outros países (EUA, França, Alemanha, Itália), que forneceram a base empírica a partir da qual se construíram os modelos de análise predominantes na literatura internacional sobre movimentos sociais. $\mathrm{O}$ tensionamento de tais modelos e a sua complexificação para apreender processos que apresentam configurações distintas são um desafio colocado, em especial, aos pesquisadores de movimentos sociais brasileiros.

\section{The hidden face of social movements: institutional transit and State-movement intersection - an analysis of the movement of Solidarity Economy in Rio Grande do Sul}

\section{Abstract}

The relations between social movements, political parties and the State has become, during the last decades, one of the central subjects of both theoretical inquiring and empirical research in the field of social movements studies. Inserted in this debate, the present paper offers an analytical perspective that allows apprehending distinct patterns of relation between institutionalized and non-institutionalized politics and, particularly, the way in which such patterns enable distinct processes of organization and action by social movements. In order to explore the analytical possibilities of such perspective, we take the trajectory of members of the so called movement of solidarity economy in the state of Rio Grande do Sul. Through these trajectories, it is possible to identify a process of organization which does not occur only out of the State's ambit, but is rather largely encouraged by governmental policies and agents. Instead of approaching and criticizing such process as a case of cooptation, manipulation or colonization of the movement 
of solidarity economy by the State, we seek to demonstrate it is the outcome of a complex pattern of relations between the civil society and the State mediated by political parties (and particularly by the Workers Party - PT) that has emerged and consolidated in Brazil during the last 25 years.

Keywords: Social movements. State/civil society/political parties' relationships. Noninstitutionalized politics. Solidarity Economy movement.

\section{Referências}

ALONSO, Ângela As teorias dos movimentos sociais: um balanço do debate. Lua Nova, São Paulo, 76, p.49-86, 2009.

BANASZAK, Lee Ann. Inside and outside the state: movement insider status, tactics and public policy achievements. In: MEYER, David S.; JENNESS, Valerie; INGRAM, Helen (eds.). Routing the opposition: social movements, public policy, and democracy. Minneapolis: University of Minnesota Press, 2005. p.149-176.

BARCELOS, Marcio. Atores, interações e escolhas: a política de silvicultura na área ambiental no Rio Grande do Sul, 2004-2009. Porto Alegre: Programa de PósGraduação em Sociologia/UFRGS (Dissertação de Mestrado), 2010.

BARREIRA, Irlys Alencar Firmo. Incômodos hóspedes? - Notas sobre a participação da Igreja e dos partidos políticos nos movimentos sociais urbanos. In: KRISCHKE, Paulo; MAINWARING, Scott (org.). A igreja nas bases em tempo de transição (1974-1985). Porto Alegre: L\&PM/CEDEC, 1986.

BOSCHI, Renato. A arte da associação: política de base e democracia no Brasil. São Paulo: Vértice, 1987.

BRESSER PEREIRA, Luiz Carlos. Sociedade Civil: sua democratização para a reforma do Estado. In: BRESSER PEREIRA, Luiz Carlos; WILHEIM, Jorge; SOLA, Lourdes (orgs.). Sociedade e Estado em transformação. São Paulo: Editora da UNESP; Brasília: ENAP, 1999.

CASTELLS, Manuel. Lutas urbanas e poder político. Porto: Afrontamento, 1976. CORADINI, Odaci. Engajamento associativo-sindical e recrutamento de elites políticas: tendências recentes no Brasil. Revista Sociologia Política, Curitiba, n. 28, p. 181-203, 2007.

CORADINI, Odaci. Em nome de quem? - Recursos sociais no recrutamento de elites políticas. Rio de Janeiro: Relume-Dumará, 2001. 
DEPSOL. Departamento de Economia Popular Solidária: documento de balanço das experiências de economia solidária no Rio Grande do Sul. Texto disponível em arquivo [.pdf], 2002.

EVANS, Peter; RUESCHEMEYER, Dietrich; SKOCPOL, Theda (eds.). Bringing the State Back In. Nova York: Cambridge University Press, 1985.

EVANS, Peter. O Estado como problema e como solução. Lua Nova, n. 28/29, p. 107-156, 1993.

EVERS, Tilman. De costas para o Estado, longe do Parlamento. Novos Estudos Cebrap, 2 (1): 25-39, abril 1983.

FALLETI, Tulia. Infiltrando o Estado: a evolução da reforma de saúde no Brasil, 1964 - 1988. Estudos de Sociologia, Araraquara, v.15, n.29, p.345-368, 2010.

FELTRAN, Gabriel de Santis. Deslocamentos - trajetórias individuais, relações entre sociedade civil e Estado no Brasil. In: DAGNINO, Evelina; OLVERA, Alberto; PANFICHI, Aldo (orgs.). A disputa pela construção democrática na América Latina. Rio de Janeiro: Paz e Terra, 2006.

FRIEDMAN, Elisabeth Jay; HOCHSTETLER, Kathryn. Assessing the third transition in Latin American democratization: representational regimes and civil society in Argentina and Brazil. Comparative Politics, Vol. 35, No. 1, pp. 21-42, Oct. 2002.

GIUGNI, Marco; McADAM, Doug; TILLY, Charles (eds.). From contention to democracy. Lanham: Rowman \& Littlefield, 1998.

GIUGNI, Marco; PASSY, Florence. Contentious politics in complex societies: new social movements between conflict and cooperation. In: GIUGNI, Marco; McADAM, Doug; TILLY, Charles (eds.). From contention to democracy. Lanham: Rowman \& Littlefield, 1998.

GOLDSTONE, Jack A. (ed.). States, parties, and social movements. Cambridge: Cambridge University Press, 2003a.

GOLDSTONE, Jack A. Introduction - Bridging institutionalized and noninstitutionalized politics. In: GOLDSTONE, Jack A. (ed.). States, parties, and social movements. Cambridge: Cambridge University Press, 2003b.

GOLDSTONE, Jack. More social movements or fewer? Beyond political opportunity structures to relational fields. Theory and Society, 33, p. 333-365, 2004.

HANAGAN, Michael. Social movements: incorporation, disengagement, and opportunities - a long view. In: GIUGNI, Marco; McADAM, Doug; TILLY, Charles (eds.). From contention to democracy. Lanham: Rowman \& Littlefield, 1998.

HARVEY, David. Condição pós-moderna: uma pesquisa sobre as origens da mudança cultural. São Paulo: Loyola, 1996. 
HOCHSTETLER, Kathryn. Democratizing pressures from below? Social movements in new Brazilian democracy. Latin American Studies Association XX International Congress, Guadalajara, México, 1997.

HOCHSTETLER, Kathryn. Organized civil society in Lula's Brazil. In: KINGSTONE, Peter R.; POWER, Tomothy J. (eds.). Democratic Brazil Revisited. Pittsburgh: University of Pittsburgh Press, 2008.

KOWARICK, Lúcio. Escritos Urbanos. São Paulo: Editora 34, 2000.

KRIESI, Hanspeter; ADAM, Silke; JOCHUM, Margit. Comparative analysis of policy networks in Western Europe. Journal of European Public Policy, 13:3, p.341361, April 2006.

LAVILLE, Jean-Louis; GAIGER, Luiz Inácio. Economia Solidária. In: CATTANI, Antonio; CORAGGIO, José Luis; LAVILLE, Jean-Louis (orgs.). Diccionário de la outra economia. Buenos Aires: Altamira, 2009. p. 169-178.

LECHAT, Noëlle. As raízes históricas da economia solidária e seu aparecimento no Brasil. Palestra proferida no II Seminário de incubadoras tecnológicas de cooperativas populares, UNICAMP, 2002.

LOSEKANN, Cristiana. A presença das organizações ambientalistas da sociedade civil no Governo Lula (2003-2007) e as tensões com os setores econômicos. Porto Alegre: Programa de Pós-Graduação em Ciência Política/UFRGS (Tese de Doutorado), 2009.

MARQUES, Eduardo. Redes sociais e instituições na construção do Estado e da sua permeabilidade. Revista Brasileira de Ciências Sociais, vol.14, noㄴ 1, p.4567, 1999.

MARQUES, Eduardo. Estado e redes sociais: permeabilidade e coesão nas políticas públicas urbanas no Rio de Janeiro. Rio de Janeiro: Revan, 2000.

MCADAM, Doug. Political process and the development of black insurgency: 1930 -1970. Chicago: University of Chicago, 1982.

McADAM, Doug. The Political Process Model. In: BUECHLER, Steven; CYLKE Jr., Kurt (eds.). Social movements: perspectives and issues. Mountain View: Mayfield, 1997.

McADAM, Doug; TARROW, Sidney; TILLY, Charles. Dynamics of contention. Cambridge: Cambridge University Press, 2001.

MEYER, David S.; JENNESS, Valerie; INGRAM, Helen (eds.). Routing the opposition: social movements, public policy, and democracy. Minneapolis: University of Minnesota Press, 2005.

MISCHE, Ann. De estudantes a cidadãos: redes de jovens e participação política. Revista Brasileira de Educação, São Paulo, n. 5/6, p. 134-150, 1997. 
MISCHE, Ann. Partisan Publics: communication and contention across Brazilian youth activist networks. Princeton: Princeton University Press, 2008.

MOISÉS, José Álvaro et alli. Cidade, povo e poder. Rio de Janeiro: CEDEC/Paz e Terra, 1982.

MORENO, Rosangela Carrilo; ALMEIDA, Ana Maria F. "Isso é política, meu!" - Socialização militante e institucionalização dos movimentos sociais. Pro-Posições, Campinas, v. 20, n. 2 (59), p. 59-76, maio/ago, 2009.

MÜLLER, Ana Luiza; SCHNEIDER, Sérgio; SILVA, Marcelo K. A construção das políticas públicas para a agricultura familiar no Brasil: o caso do Programa de Aquisição de Alimentos. Trabalho apresentado no GT de políticas públicas do $31^{\circ}$ Encontro Anual da ANPOCS, Caxambu/MG, 2007.

OLIVEIRA, Francisco de. Acumulação monopolista, Estado e urbanização: a nova qualidade do conflito de classes. In: MOISÉS, José Álvaro; MARTINEZ-ALIER, Verena; OLIVEIRA, Francisco de; SOUZA, Sérgio de. Contradições urbanas e movimentos sociais. $3^{\mathrm{a}} \mathrm{ed}$. Rio de Janeiro: Paz e Terra/CEDEC, 1978.

OLIVEIRA, Gerson de Lima. Permeabilidade e trânsito institucional: a relação entre sociedade civil e Estado a partir das trajetórias de militantes-gestores nas políticas de economia solidária no Rio Grande do Sul - os casos de Porto Alegre (1996-2004) e do Governo Estadual (1999-2002). Porto Alegre: Programa de PósGraduação em Sociologia/UFRGS (Dissertação de Mestrado), 2011.

OLIVEIRA, Wilson Ferreira Engajamento político, competência e elites dirigentes do movimento ambientalista. Revista de Sociologia e Política, v. 16, p. 167-186, 2008.

RIETHOF, Marieke. Changing strategies of the Brazilian Labor Movement: from opposition to participation. Latin American Perspectives, Vol.31, No.6, p.31-47, Nov, 2004.

SADER, Eder. Quando novos personagens entraram em cena. Rio de Janeiro: Paz e Terra, 1988.

SEIDL, Ernesto. Disposições a militar e lógica de investimentos militantes. ProPosições, Campinas, v. 20, n. 2 (59), p. 21-39, maio/ago, 2009.

SILVA, Marcelo Kunrath. De volta aos movimentos sociais? Reflexões a partir da literatura brasileira recente. Ciências Sociais Unisinos, São Leopoldo, Vol. 46, n. 1, p. 2-9, jan/abr, 2010.

SINGER, Paul; SOUZA, André Ricardo. A economia solidária no Brasil: a autogestão como resposta ao desemprego. São Paulo, Contexto, 2000.

TARROW, Sidney. Struggle, politics, and reform: collective action, social movements, and cycles of protest (Western Societies Program, Occasional Paper number 21). Ithaca: Cornell University Press, 1989. 
TARROW, Sidney. Transnational politics: contention and institutions in international politics. Annual Review of Political Science, 4, p. 1-20, 2001.

TARROW, Sidney. Poder em movimento: movimentos sociais e confronto político. Petrópolis: Vozes, 2009.

TELLES, Vera da Silva. Anos 70: experiências, práticas e espaços políticos. In: KOWARICK, Lúcio (org.). As lutas sociais e a cidade: São Paulo passado e presente. Rio de Janeiro: Paz e Terra, 1988.

TILLY, Charles. Contentious repertoires in Great Britain, 1758-1834. In: TRAUGOTT, Mark (ed.). Repertoires and cycles of collective action. Durham: Duke University Press, 1995.

TILLY, Charles. Regimes and repertoires. Chicago: University of Chicago Press, 2006.

TILLY, Charles; TARROW, Sidney. Contentious politics. Boulder: Paradigm Publishers, 2007.

WEYLAND, Kurt. Democracy without equity: failures to reform in Brazil. Pittsburgh: University of Pittsburgh Press, 1996.

\section{Páginas de internet}

ATLAS DA ES: http://www.mte.gov.br/ecosolidaria/sies_ATLAS_PARTE_1.pdf

CÁRITAS: www.caritas.org.br

FBES: http://www.fbes.org.br/

FGEPS: http://forumgauchoeps.wordpress.com/

SENAES: http://www.mte.gov.br/ecosolidaria/prog_default.asp

SIES: http://www.mte.gov.br/ecosolidaria/sies.asp

Recebido em: 02/06/2011

Aceite final: 04/08/2011 